\title{
A Universal Framework For Systemizing the Evaluation of Immersive And Collaborative Performance*
}

\author{
Laurent Dupont \\ Université de Lorraine, ERPI, F-54000, Nancy \\ France \\ \{1.dupont\}@univ-lorraine.fr
}

\author{
Marc Pallot, Olivier Christmann, Simon Richir \\ Arts et Metiers ParisTech, LAMPA, 49000 Angers \\ France \\ \{firstname.lastname\}@ensam.eu
}

\begin{abstract}
The capacity to visually represent innovative product/service ideas and concepts as well as usage scenarios while anticipating the resulting User eXperience (UX) is extremely critical in order to ensure innovation success. Our previous empirical studies on low-cost Immersive Virtual Environments (IVE), and, more recently, on Immersive Collaborative Environments (ICE) have unveiled the great potential of 'close-to-real-life' immersion. It fulfills the necessary level of realism in order to engage and facilitate stakeholders' contribution to alternative solutions and usage scenarios. Therefore, this paper is intended to present our ICE framework that could be used in investigations of Immersive and Collaborative performances.
\end{abstract}

\section{CCS CONCEPTS}

- General and reference $\rightarrow$ Evaluation - Human-centered computing $\rightarrow$ Virtual reality $\bullet$ Human-centered computing $\rightarrow$ Collaborative interaction $\cdot$ Human-centered computing $\rightarrow$ Mixed / augmented reality • Human-centered computing $\rightarrow$ Interaction design process and methods • Human-centered computing $\rightarrow$ User interface design

\section{KEYWORDS}

Immersive Virtual Environment; Virtual Reality; User eXperience, Living Lab; eXperience Design; Collaboration

\section{ACM Reference format:}

Laurent Dupont, Marc Pallot, Olivier Christmann, Simon Richir. 2018. A Universal Framework For Systemizing the Evaluation of Immersive And Collaborative Performance. In VRIC '18: Virtual Reality International Conference - Laval Virtual VRIC '18, April 4--6, 2018, LAVAL, France, 10 pages. https://doi.org/10.1145/3234253.3234306

\footnotetext{
* (C) 2018 Association for Computing Machinery. ACM acknowledges that this contribution was authored or co-authored by an employee, contractor or affiliate of a national government. As such, the Government retains a nonexclusive, royalty-free right to publish or reproduce this article, or to allow others to do so, for Government purposes only.

VRIC '18, April 4-6, 2018, LAVAL, France (C) 2018 Association for Computing Machinery. ACM ISBN 978-1-4503-5381-6/18/04 ..\$15.00 https://doi.org/10.1145/3234253.3234306
}

\section{INTRODUCTION}

In this paper, we present, based on our ICE previous investigation [1,2], a universal framework, which includes a revised version of our ICE model and construct as well as mixed methods instrument. This evaluation framework is intended for systemizing immersive and collaborative performance evaluation. It is important to understand that the term 'collaborative' reflects the co-creation [3] activities where all project stakeholders, especially users, are intended to actively contribute to the emergence of innovative ideas and concepts as well as usage scenarios. Within the Living-Labs community, co-creation is the ingredient that allows turning users, from being observed subjects, into contributors of value creation [4]. Co-creation is one of the most important activities of the eXperience Design iterative process that is composed of four activities, namely: Co-creation, Exploration, Experimentation and Evaluation. It is intended for creating innovative ideas, concepts and usage scenarios in order to fulfill identified value elements. During the exploration activity, value elements are converted into UX elements that will be assembled in order to form the UX instantiated model [5]. Then, UX data collected during the experimentation activities enable the anticipation of the future UX; hence, the ability to envision the potential level of technology acceptance and product or service adoption when the innovative product or service will be ready to market. This is an essential difference with users observation-led design approaches like contextual design or even design thinking where ethnographic studies (user observation) are more traditional.

Immersive Collaborative Environments (ICE), which are IVEs intended for several users working together, have been, upto-now, often implemented through the use of a CAVE (Cave Automated Virtual Environment). As we previously explained, CAVE solutions constitute an ICE where it is possible to immerse a limited number of participants that could, on the one hand, interact with the environment and, on the other hand, vocally interact among themselves. However, CAVE solutions are not so affordable for SMEs and especially Start-ups. Recently, low-cost immersive technologies have emerged. It further explains why we want to experiment and evaluate different ICE platforms that could be more affordable for small organizations. Besides discussing the ICE framework within the context of Virtual Reality (VR), Augmented Reality (AR) and Mixed Reality (MR) 
technologies, our main goal is to allow SMEs, especially start-ups, to properly evaluate immersive and collaborative solutions they design or intend to use. In this paper, we present the conceptual framework that supports the evaluation of ICEs implemented with dedicated technologies.

The second section of this paper describes the previous work and cites the main scientific contributions. The third section explains the technological context of implementing 'low-cost' devices. Section four presents the original development of the framework dedicated to the evaluation of immersive and collaborative performances. We conclude this paper in discussing the limits of this study and provide potential perspectives.

Table 1: Papers distribution by ICE facets, elements and proprieties

\begin{tabular}{|c|c|c|c|c|c|c|c|c|c|c|c|c|c|c|c|c|c|c|c|c|c|c|c|}
\hline \multirow{3}{*}{ Authors } & \multirow{3}{*}{$\begin{array}{l}0 \\
0 \\
0 \\
\frac{0}{0} \\
\frac{0}{2}\end{array}$} & \multirow{3}{*}{ 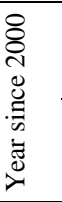 } & \multicolumn{8}{|c|}{ Collaborative eXperience } & \multicolumn{13}{|c|}{ Immersive eXperience } \\
\hline & & & \multicolumn{2}{|c|}{ SMa } & \multicolumn{2}{|c|}{$\mathrm{TB}$} & \multicolumn{2}{|c|}{$\mathrm{SMe}$} & \multicolumn{2}{|c|}{ MU } & \multicolumn{3}{|c|}{ RwD } & \multicolumn{3}{|c|}{ PI } & \multicolumn{2}{|c|}{$\mathrm{CI}$} & & & & EI & \\
\hline & & & $\sum_{\infty}^{u}$ & $\sum_{n}^{\frac{\alpha}{\pi}}$ & $\stackrel{E}{E}$ & Un & $\frac{\sqrt[n]{u}}{\sum_{\infty}^{\infty}}$ & $\sum_{\infty}^{U}$ & $\begin{array}{l}0 \\
己\end{array}$ & $\stackrel{\circlearrowright}{\Xi}$ & $\stackrel{5}{\stackrel{5}{2}}$ & 官 & $\stackrel{\vec{\alpha}}{\underline{a}}$ & $\stackrel{\tilde{\Omega}}{\tilde{\Omega}}$ & $\frac{n}{n}$ & $\frac{\hat{\Omega}}{\underline{\Omega}}$ & 当 & $\underset{\mho}{\mho}$ & $\frac{\tilde{U}}{\tilde{S}}$ & $\overline{\tilde{n}}$ & 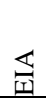 & 是 & 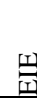 \\
\hline Agarwal \& Karahanna & [6] & 00 & & & & & & & & & $\mathrm{X}$ & & & $\mathrm{Y}$ & $\mathrm{Y}$ & & $\mathrm{X}$ & $\mathrm{X}$ & & & $\mathrm{Y}$ & $\mathrm{Y}$ & $\mathrm{Y}$ \\
\hline Bailenson et al. & [7] & 03 & & & & & & & & & & & & & & & & & $\mathrm{X}$ & $\mathrm{X}$ & & & \\
\hline Hoyt et al. & [8] & 03 & & & & & & & & & & & & & & & & & $\mathrm{X}$ & $\mathrm{X}$ & & & \\
\hline Brown and Cairns & [9] & 04 & & & & & & & & & & & & & & & $\mathrm{X}$ & & & & $\mathrm{X}$ & $\mathrm{X}$ & $\mathrm{X}$ \\
\hline Bente et al. & {$[10]$} & 04 & $\mathrm{Y}$ & $\mathrm{X}$ & $\mathrm{X}$ & $\mathrm{X}$ & & & $\mathrm{X}$ & $\mathrm{X}$ & & & & & $\mathrm{X}$ & & & & $\mathrm{X}$ & $\mathrm{X}$ & & & $\mathrm{Y}$ \\
\hline Narayan et al. & {$[11]$} & 05 & $\mathrm{X}$ & & & & & & $\mathrm{X}$ & $\mathrm{X}$ & & & & $\mathrm{X}$ & $\mathrm{X}$ & $\mathrm{X}$ & $\mathrm{X}$ & & & $\mathrm{X}$ & $\mathrm{X}$ & & \\
\hline Louchart et al. & {$[12]$} & 06 & & & $\mathrm{X}$ & & & & $\mathrm{X}$ & & & & & & & $\mathrm{X}$ & $\mathrm{X}$ & & $\mathrm{X}$ & $\mathrm{X}$ & & & $\mathrm{X}$ \\
\hline Antoniac et al. & {$[13]$} & 06 & $\mathrm{Y}$ & $\mathrm{Y}$ & $\mathrm{X}$ & & $\mathrm{X}$ & $\mathrm{X}$ & $\mathrm{Y}$ & $\mathrm{Y}$ & & & & $\mathrm{X}$ & $\mathrm{Y}$ & & & & & $\mathrm{X}$ & & & $\mathrm{Y}$ \\
\hline Jennett et al. & {$[14]$} & 08 & $\mathrm{X}$ & & & & & & & & $\mathrm{X}$ & $X$ & $\mathrm{X}$ & $\mathrm{X}$ & $\mathrm{X}$ & $X$ & $\mathrm{X}$ & $\mathrm{X}$ & $\mathrm{X}$ & $\mathrm{X}$ & $\mathrm{X}$ & $\mathrm{X}$ & $\mathrm{X}$ \\
\hline Jennett et al. & {$[15]$} & 09 & & & & & & & & & $\mathrm{X}$ & $\mathrm{X}$ & & & & & $\mathrm{X}$ & $\mathrm{X}$ & & & $\mathrm{X}$ & $\mathrm{X}$ & $\mathrm{X}$ \\
\hline Brockmyer and Fox & {$[16]$} & 09 & & & & & & & & & $\mathrm{X}$ & $\mathrm{X}$ & & & & $\mathrm{X}$ & $\mathrm{X}$ & $\mathrm{X}$ & & & $\mathrm{X}$ & $\mathrm{X}$ & $\mathrm{X}$ \\
\hline Stuart & {$[17]$} & 10 & & & & & & & & & $\mathrm{X}$ & $\mathrm{Y}$ & & & & & $\mathrm{X}$ & $\mathrm{X}$ & $\mathrm{X}$ & $\mathrm{X}$ & $\mathrm{Y}$ & & $\mathrm{X}$ \\
\hline Sanders \& Cairns & {$[18]$} & 10 & & & & & & & & & $\mathrm{X}$ & $\mathrm{X}$ & & & & $\mathrm{X}$ & $\mathrm{X}$ & $\mathrm{Y}$ & & & $\mathrm{X}$ & & \\
\hline Calleja & [19] & 11 & & & & & & & & & & & & $\mathrm{X}$ & & & & & & & & $\mathrm{X}$ & $\mathrm{X}$ \\
\hline Gestwicki et al. & {$[20]$} & 12 & & & & & & & & & & & & & & & $\mathrm{X}$ & & & & & $\mathrm{X}$ & \\
\hline Lu et al. & {$[21]$} & 12 & & & & & & & & & & & & & & & $\mathrm{X}$ & $\mathrm{X}$ & & & $\mathrm{X}$ & $\mathrm{X}$ & $\mathrm{X}$ \\
\hline Mustaro \& Mendonça & {$[22]$} & 12 & & & & & & & & & & & & & & & & & & & $\mathrm{X}$ & $\mathrm{X}$ & $\mathrm{X}$ \\
\hline Pallot & {$[23]$} & 12 & $\mathrm{X}$ & $\mathrm{X}$ & $\mathrm{X}$ & $\mathrm{X}$ & $\mathrm{X}$ & $\mathrm{X}$ & $\mathrm{X}$ & $\mathrm{X}$ & & & & & & & & $\mathrm{X}$ & & $\mathrm{X}$ & & & $\mathrm{X}$ \\
\hline Schnall et al. & [24] & 12 & & & & & & & & & & & & $\mathrm{X}$ & & & $\mathrm{X}$ & & & & & & \\
\hline Lorenzo & {$[25]$} & 12 & $\mathrm{Y}$ & $\mathrm{X}$ & $\mathrm{X}$ & $\mathrm{X}$ & $\mathrm{X}$ & & $\mathrm{X}$ & $\mathrm{X}$ & & & & $\mathrm{X}$ & & $\mathrm{X}$ & $\mathrm{X}$ & & $\mathrm{X}$ & $\mathrm{X}$ & & $\mathrm{X}$ & $\mathrm{X}$ \\
\hline Dupont et al. & {$[26]$} & 12 & & & & & & & $\mathrm{X}$ & $\mathrm{X}$ & & & & & & & & & & & & & \\
\hline Ştefan & [27] & 12 & & & & & $\mathrm{X}$ & & & $\mathrm{Y}$ & & & & & & & & & & & & & \\
\hline Cox et al & [28] & 12 & & & & & & & & & $\mathrm{X}$ & & & $\mathrm{Y}$ & & $\mathrm{X}$ & $\mathrm{X}$ & $\mathrm{X}$ & & & & $\mathrm{X}$ & $\mathrm{X}$ \\
\hline Thompson et al. & [29] & 12 & & & & & & & & & & & & & & $\mathrm{X}$ & $\mathrm{X}$ & & & & & & \\
\hline Santos et al. & {$[30]$} & 12 & $\mathrm{X}$ & $\mathrm{X}$ & $\mathrm{X}$ & & $\mathrm{X}$ & & $\mathrm{X}$ & & & & & & & & & & & & & & \\
\hline Pallot et al. & {$[31]$} & 13 & & & & & & & & & & & & & & $\mathrm{X}$ & $\mathrm{X}$ & & $\mathrm{X}$ & $\mathrm{X}$ & & & \\
\hline Nordin et al. & {$[32]$} & 13 & & & & & & & & & $\mathrm{X}$ & $\mathrm{X}$ & $\mathrm{X}$ & & & & & & & & & & \\
\hline Nakevska et al. & {$[33]$} & 14 & & & & & & & & & & & & & $\mathrm{X}$ & $\mathrm{X}$ & & & & & & $\mathrm{X}$ & \\
\hline Cruz et al. & [34] & 14 & $\mathrm{X}$ & & & & & & & & & & & & & & & & $\mathrm{X}$ & $\mathrm{X}$ & & & \\
\hline Nordin et al. & {$[35]$} & 14 & & & & & & & & & $\mathrm{X}$ & $X$ & & $\mathrm{X}$ & $\mathrm{X}$ & $X$ & $\mathrm{X}$ & $\mathrm{X}$ & & $X$ & $\mathrm{X}$ & $\mathrm{X}$ & $\mathrm{X}$ \\
\hline Freina \& Ott & {$[36]$} & 15 & & & & & & & $\mathrm{X}$ & & & & & $\mathrm{X}$ & $\mathrm{X}$ & $\mathrm{X}$ & $\mathrm{X}$ & & & & $\mathrm{Y}$ & & $\mathrm{Y}$ \\
\hline Eynard et al. & [37] & 15 & & & & & & & $\mathrm{X}$ & $\mathrm{X}$ & & & & & & $\mathrm{X}$ & $\mathrm{X}$ & & $\mathrm{X}$ & $\mathrm{X}$ & $\mathrm{X}$ & $\mathrm{X}$ & \\
\hline Orenstein et al. & [38] & 15 & $\mathrm{Y}$ & $\mathrm{Y}$ & & & $\mathrm{Y}$ & & $\mathrm{Y}$ & $\mathrm{Y}$ & $\mathrm{X}$ & $\mathrm{Y}$ & $\mathrm{Y}$ & $\mathrm{X}$ & & $\mathrm{Y}$ & & $\mathrm{Y}$ & $\mathrm{Y}$ & $\mathrm{Y}$ & $\mathrm{X}$ & $\mathrm{X}$ & $\mathrm{X}$ \\
\hline Roth & [39] & 15 & & & $\mathrm{Y}$ & & & & & & $\mathrm{Y}$ & $\mathrm{Y}$ & & $\mathrm{Y}$ & $\mathrm{X}$ & $\mathrm{X}$ & $\mathrm{X}$ & $\mathrm{X}$ & $\mathrm{X}$ & $\mathrm{X}$ & $\mathrm{X}$ & $\mathrm{X}$ & $\mathrm{X}$ \\
\hline Dupont et al. & {$[40]$} & 16 & & & & & & & & & & & & & & $\mathrm{X}$ & & & $\mathrm{X}$ & $\mathrm{X}$ & & & $\mathrm{X}$ \\
\hline Zhang et al. & {$[41]$} & 16 & & & & & & & & & & & & $\mathrm{X}$ & $\mathrm{X}$ & & $\mathrm{X}$ & & & & & & \\
\hline Ke et al. & {$[42]$} & 16 & & & & & & & $\mathrm{X}$ & $\mathrm{X}$ & & & & $\mathrm{X}$ & & & & & & & & & \\
\hline Pallot \& Richir & {$[43]$} & 16 & $\mathrm{Y}$ & & & & $\mathrm{Y}$ & $\mathrm{Y}$ & & $\mathrm{Y}$ & $\mathrm{X}$ & & & $\mathrm{X}$ & $\mathrm{X}$ & $\mathrm{X}$ & $\mathrm{Y}$ & $\mathrm{Y}$ & $\mathrm{Y}$ & $\mathrm{Y}$ & & & $\mathrm{X}$ \\
\hline Serrano et al. & {$[44]$} & 16 & & & & & & & & & & & & $\mathrm{X}$ & & $\mathrm{X}$ & & & & & $\mathrm{Y}$ & $\mathrm{Y}$ & $\mathrm{Y}$ \\
\hline Pouliquen-Lardy & {$[45]$} & 16 & $\mathrm{X}$ & $\mathrm{X}$ & & & $\mathrm{X}$ & $\mathrm{Y}$ & $\mathrm{X}$ & & & & & $\mathrm{X}$ & & $\mathrm{X}$ & & & $\mathrm{X}$ & & & & \\
\hline Ulewicz et al. & {$[46]$} & 16 & $\mathrm{X}$ & $\mathrm{X}$ & & & $\mathrm{Y}$ & & $\mathrm{Y}$ & & & & & & & $X$ & & & $\mathrm{Y}$ & $\mathrm{X}$ & $\mathrm{X}$ & & $\mathrm{X}$ \\
\hline Gabana et al. & {$[47]$} & 16 & & & & & & & $\mathrm{X}$ & $\mathrm{X}$ & & & & & $\mathrm{X}$ & $\mathrm{Y}$ & & & $\mathrm{Y}$ & $\mathrm{X}$ & $\mathrm{X}$ & $\mathrm{X}$ & $\mathrm{X}$ \\
\hline Roth and Koenitz & {$[48]$} & 16 & & & & & & & & & & $\mathrm{Y}$ & $\mathrm{Y}$ & $\mathrm{Y}$ & $\mathrm{Y}$ & $\mathrm{X}$ & $\mathrm{Y}$ & $\mathrm{Y}$ & $\mathrm{X}$ & $\mathrm{Y}$ & $\mathrm{X}$ & $\mathrm{X}$ & $\mathrm{X}$ \\
\hline Le et al. & [49] & 17 & & & $\mathrm{Y}$ & & $\mathrm{Y}$ & $\mathrm{Y}$ & $\mathrm{Y}$ & & & & & & & & & & & & & & \\
\hline Fu \& Hwang & {$[50]$} & 18 & $\mathrm{Y}$ & & $\mathrm{X}$ & & $\mathrm{X}$ & & $\mathrm{X}$ & $\mathrm{X}$ & & & & & & & & & & & & & \\
\hline Du et al. & {$[51]$} & 18 & & $\mathrm{Y}$ & $\mathrm{Y}$ & & & & $\mathrm{X}$ & & & & & & & & & $\mathrm{Y}$ & & $\mathrm{Y}$ & & & \\
\hline Li et al. & {$[52]$} & 18 & & & & & $\mathrm{X}$ & & $\mathrm{X}$ & & & & & $\mathrm{X}$ & & $\mathrm{X}$ & $\mathrm{X}$ & & & $\mathrm{X}$ & $\mathrm{X}$ & & \\
\hline
\end{tabular}




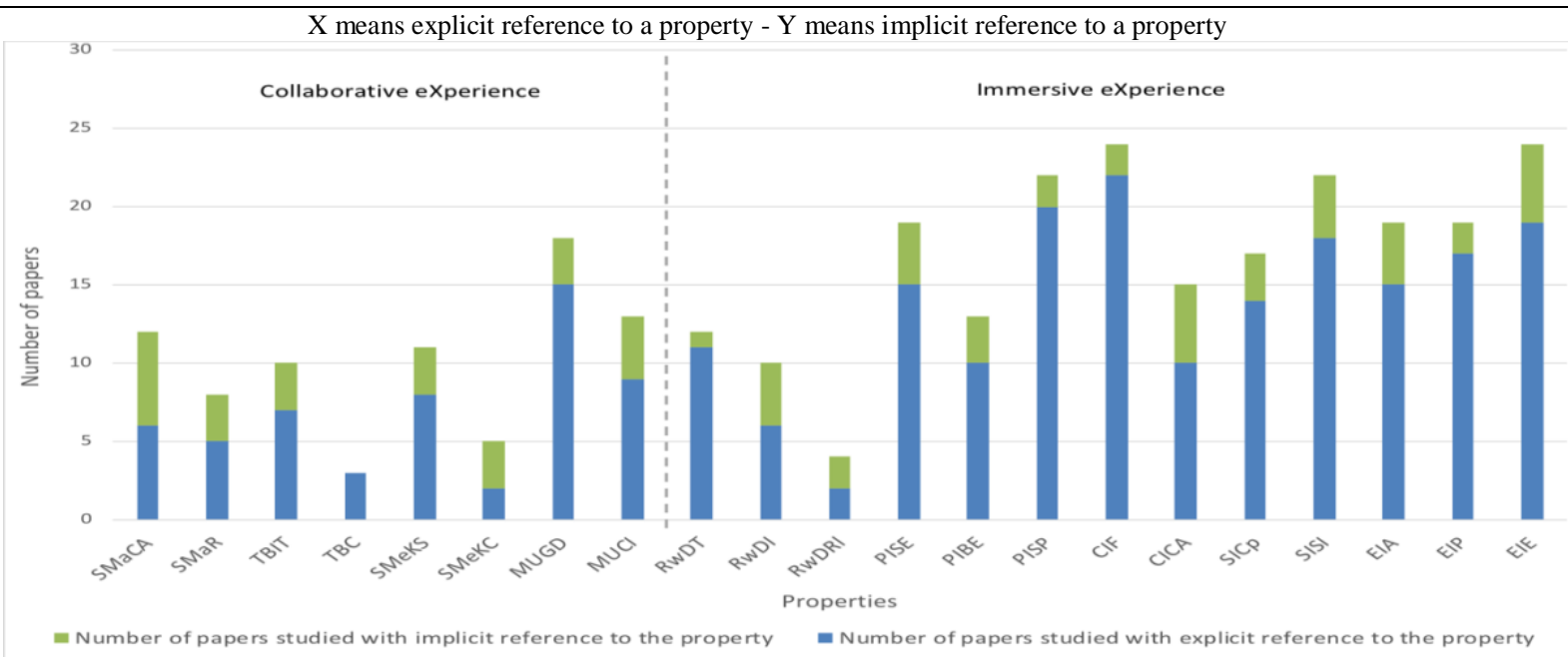

Figure 1: Number of papers quoting a property or a close concept, bar chart based on Table 1

\section{PREVIOUS WORK}

We have previously $[1,2]$ introduced most of the concepts used in this domain, such as: Co-creation, Immersive Platforms, Immersion, Social Immersion, Immersion and collaboration. We have identified new available empirical studies published in 2017 and 2018 that were included as an update. Overall, we have analyzed 45 international scientific papers [6-16,18-44,46-52], one thesis written in French [45], and one specialized press article 2000 [17] published since 2000 (see Table 1).

There are mainly three publication streams dedicated to immersive co-creation, namely: Immersive Virtual Environment (IVE), Immersive Collaborative Environments (ICE) and Collaborative Virtual Environments (CVE). There are numbers of empirical studies on different immersive technology platforms that were conducted through experiments involving several participants (see Table 1).

These 47 publications allow us to confirm the four elements constituting the Collaborative eXperience (CX) (see Table 2): Sense Making (SMa), Trust Building (TB), Shared Meanings (SMe), and Mutual Understanding (MU); and the five elements constituting the Immersive eXperience (IX): Real-Word Dissociation (RwD), Perceptual Immersion (PI), Cognitive Immersion (CI), Social Immersion (SI), and Emotional Immersion (EI) [1]. Furthermore, these papers highlighted the properties behind the nine elements of the ICE Model [1]. Thus, eight properties address the Collaborative eXperience, while thirteen others address the Immersive eXperience. Often, authors made an explicit reference to the properties, naming the property or using a synonym (identified by the character ' $\mathrm{X}$ ' in the table of the Table 1). Other times, authors seem made an implicit reference (identified by the character ' $\mathrm{Y}$ ' in the table of the Table 1). Sometimes, authors did not focus specifically on these properties, but their studied context or results gave clues or indirect evidences.

Table 2: Papers distribution by ICE elements

\begin{tabular}{|c|c|}
\hline Element & References \\
\hline \multicolumn{2}{|c|}{ Collaborative eXperience } \\
\hline $\begin{array}{l}\text { Sense Making } \\
\text { (SMa) }\end{array}$ & $\begin{array}{l}{[10][11][13][14][23][25][30][34][38][43]} \\
{[45][46][50][51]}\end{array}$ \\
\hline $\begin{array}{l}\text { Trust Building } \\
\text { (TB) }\end{array}$ & [10] [12] [13] [23] [25] [30] [39] [49] [50] [51] \\
\hline $\begin{array}{l}\text { Shared Meanings } \\
\text { (SMe) }\end{array}$ & $\begin{array}{l}{[13][23][25][27][30][38][43][45][46][49]} \\
500][52]\end{array}$ \\
\hline Mutual & {$[10][11][12][13][23][25][26][27][30][36]$} \\
\hline $\begin{array}{l}\text { Understanding } \\
\text { (MU) }\end{array}$ & $\begin{array}{l}{[37][38][42][43][45][46][47][49][50][51]} \\
{[52]}\end{array}$ \\
\hline \multicolumn{2}{|c|}{ Immersive eXperience } \\
\hline Real-Word & [6] [14] [15] [16] [17] [18] [28] [32] [35] [38] [39] \\
\hline $\begin{array}{l}\text { Dissociation } \\
(\mathrm{RwD})\end{array}$ & [43] [48] \\
\hline Perceptual & [6] [10] [11] [12] [13] [14] [16] [18] [19] [24] [25] \\
\hline $\operatorname{Immersion}(\mathrm{PI})$ & $\begin{array}{l}{[28][29][31][33][35][36][37][38][39][40]} \\
{[41][42][43][44][45][46][47][48][52]}\end{array}$ \\
\hline Cognitive & [6] [9] [10] [11] [12] [14] [15] [16] [17] [18] [20] \\
\hline $\operatorname{Immersion}(\mathrm{CI})$ & $\begin{array}{l}{[21][23][24][25][29][31][35][36][37][38]} \\
{[39][41][43][48][52]}\end{array}$ \\
\hline $\begin{array}{l}\text { Social Immersion } \\
\text { (SI) }\end{array}$ & $\begin{array}{l}{[7][8][10][11][12][13][14][17][23][25][28]} \\
{[31][34][35][37][38][39][40][43][45][46]} \\
{[47][48][51][52]}\end{array}$ \\
\hline Emotional & [6] [9] [10] [11] [12] [13] [14] [15] [16] [17] [18] \\
\hline Immersion (EI) & $\begin{array}{l}{[19][20][21][22][23][25][28][35][36][37]} \\
{[38][39][40][43][44][46][47][48][52]}\end{array}$ \\
\hline
\end{tabular}

The papers distribution by property is presented in a bar chart highlighting the number of explicit and implicit references 
to each property (see Figure 1). Globally, the literature review provides more papers related to IX than CX. All the properties have at least 2 explicit references, however, there are significant differences. 'Flow', also described as balanced skill/challenge, is the most immersive property. This property is part of Cognitive Immersion, thus we adopt 'CIF' as acronym.

Properties of Perceptual, Cognitive, Social and Emotional Immersions are pretty well analyzed in these papers. Real-Word Dissociation (RwD) is also a relevant characteristic for immersion, even if 'Respond-less to external event' (RwDRl) is seldom mentioned. Regarding the CX, 'Group Dynamic' (MUGD) and 'Collective intelligence' (MUCI) are the most quoted. Several other properties, namely: 'Context Awareness' (SMaCA), 'Relevance' or 'Disambiguation' (SMaR), 'Interpersonal Ties' (TBIT, and 'Knowledge Sharing' (SMeKS) are quoted by five to 12 papers. Finally, 'Confidence' (TBC) and 'Knowledge Creation' (SMeKC) are the less studied properties in these listed papers.

However, these two last properties are very well known for companies collaborating with suppliers or customers. For example, B-to-B relationships based on confidence reduce risks and transaction costs [53]. This aspect is particularly true at the level of innovation and creativity processes [54].

Literature review underlines the diversity of characteristics describing immersive and collaborative experiences. These properties are not all studied with the same intensity. Nevertheless, we assume that we have to take into account all of these characteristics for the evaluation of Immersive and Collaborative Performances, until we will reach a validated model. However, it remains open to further investigate why these properties are not so studied while their potential impact on cocreation and collective innovation.

\section{EXPERIMENTAL PLATFORMS AND FIRST ANALYSIS}

\subsection{Immersive and Collaborative technologies}

The setup of the experiment, which includes four different ICE (see Figure 2), was used for running co-creation workshops already described in $[2,40]$. These four ICE were the followings: (1) the Computer Screen platform (picture a) allows several participants to use and work collectively on one or several laptops or personal computers; (2) the collaborative interfaces on Multitouch Tables platform or tactile wall (picture b) allows three or four users to interact with an ad hoc software; (3) the LF2L Immersive Bubble platform (picture c) generates an original collective user experiences for three or four people; (4) an Head Mounted Display (HMD) platforms and its ad hoc virtual contents (picture d) gives the possibility to a person to be immersed in a particular scene; in this particular case, other participants can follow the visual immersion that is reflected on a display while all the participants can interact verbally together and collaborate.

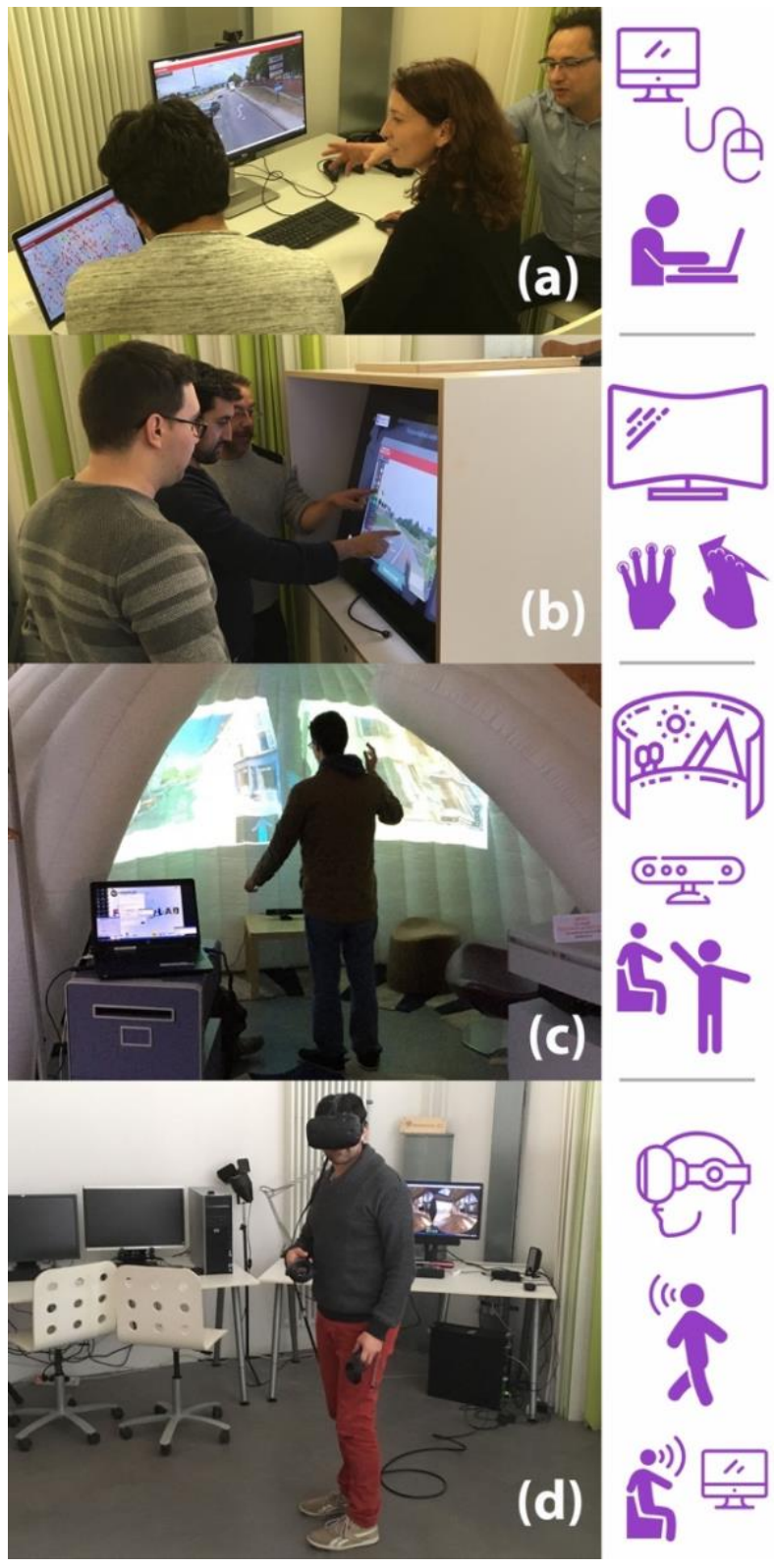

Figure 2: Pictures of LF2L showing the "low-cost" immersive technologies supporting ICE experiments adapted from [1,2]

\subsection{Operational feedback}

Our previous experimental results [2] have shown that it is better to give advices and train participants for a few minutes in order to get them a little used with these technologies. Indeed, in this experiment, the purpose is to evaluate immersion and collaboration performances between people. It is necessary to minimize the risk of not understanding a technology and avoid generate barriers between people. Nevertheless, we observed a form of collaboration between participants seeking to understand how platforms work. Furthermore, during our first experiment, we also identified that participants adopted a 'kind of solidarity spirit' 
within Immersive Collaborative Environments [2]. These results come from a previous exploratory questionnaire evaluating the direct impact of ICE on immediate collaboration. In fact, we evaluated the CX dimension on the short term. Further research is necessary to measure the long-term performance. How Immersive Collaborative Environments support sustainable co-creation or wider collaborative innovation?

Moreover, we noted the importance of the design of the case study so that, during the experiment, the collaboration is essential to the resolution of the case. With our first experiment, it seems that everything has happened as if the technological difficulties have compensated the low level of complexity of our case study. This specific context spurred an original collaboration. How to design relevant experiments (complex case study) supporting ICE research?

We hypothesize that, in the near future, individuals will better accept and control immersive technologies. The use of VR or AR will become common for individuals' activities. With that in mind, how to easily identify relevant situations requiring collaboration and immersion?

Several research questions appear with our exploratory approach. A research agenda emerged, and we continue to design the instrumentation seeking to comprehend together the immersive and collaborative experiences. The next step is to design a tool to evaluate these two aspects of immersiveness and collaborativeness.

\section{DEVELOPMENTS OF THE INSTRUMENT}

\subsection{ICE Tree Structure as framework of evaluation}

As presented in our previous papers [1,2], the elaborated ICE structure is a tree structure that includes both the co-creation or collaboration and immersion sides; like the two sides of a same coin. As shown in the Figure 3, the immersion side is turned into the IX facet and the 'co-creation' side is turned into the CX facet. The overall UX is then composed of the CX and IX facets. Both include cognitive and social elements while the immersion side owns the perceptual and emotional elements. The Figure 3 presents a refinement of our previous ICE tree structure [1,2] according to the new elements inherited from the Table 1 and the Table 2.

Currently, as described in the first section, we identified that eight properties are behind CX and thirteen behind IX. Thus, the challenge remains to design an evaluation framework that includes both facets of the overall UX. Furthermore, it is necessary to find out, through a statistical analysis, whether the co-creation and immersion facets' elements and properties are correlated. The existing surveys identified during the literature review are either dedicated to Immersive environments or Collaborative environments. There is not yet specific survey evaluating both Immersive and Collaborative Performances.

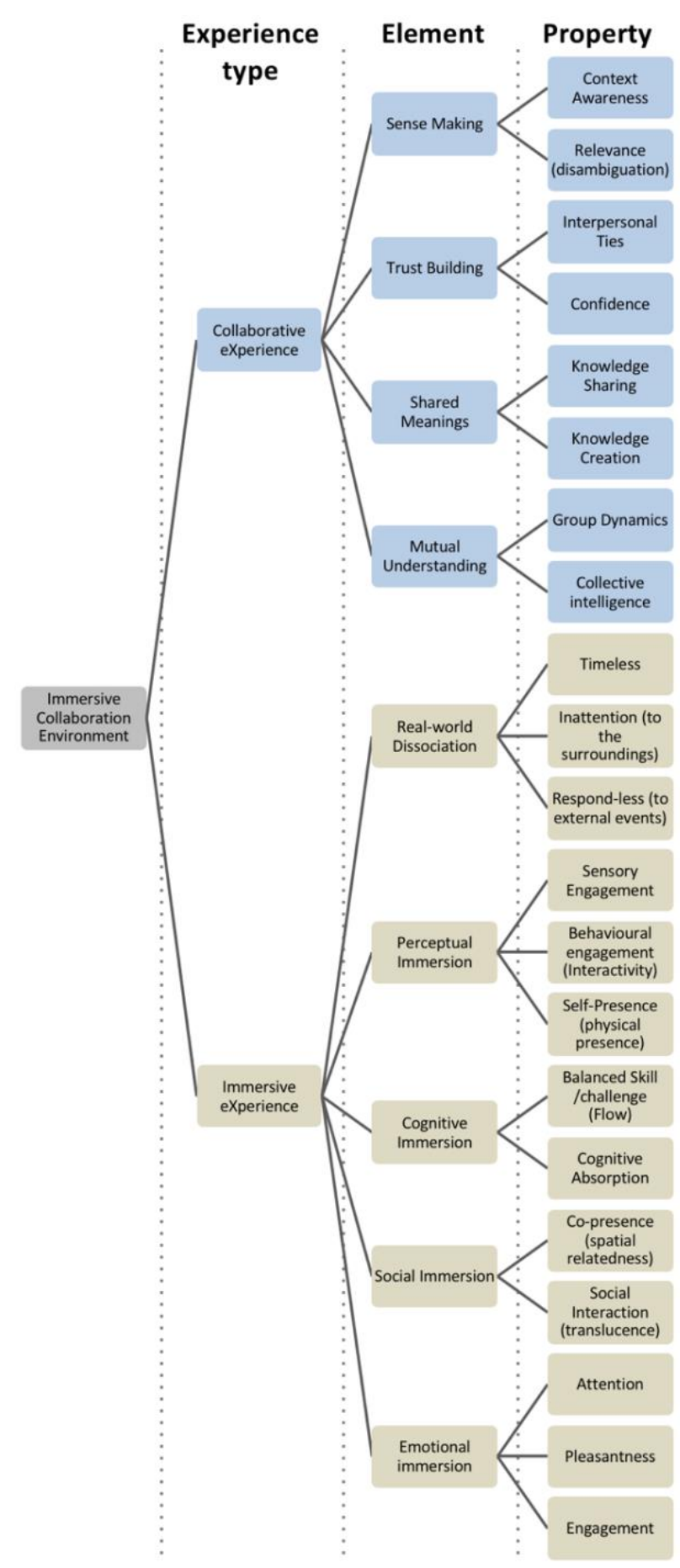

Figure 3: ICE Tree Structure based on synthetized elements of the Table 1, adapted from [1,2]

In terms of instrument, we adopted a Bipolar Survey [55], which includes at least three questions by property for statistical purpose. For each question, we identify specific antonyms or 
bipolar words (adjectives preferably) corresponding to a specific property and a semantic scale of 5 degrees ( 2 negatives and 3 positives). Participants are asked to rate each CX and IX property according to the semantic scale; for example: -2 Useless, -1, Mostly Useless, 1 almost Useful, 2 Mostly Useful, 3 Useful.

\subsection{Evaluation of the $\mathrm{CX}$ dimension}

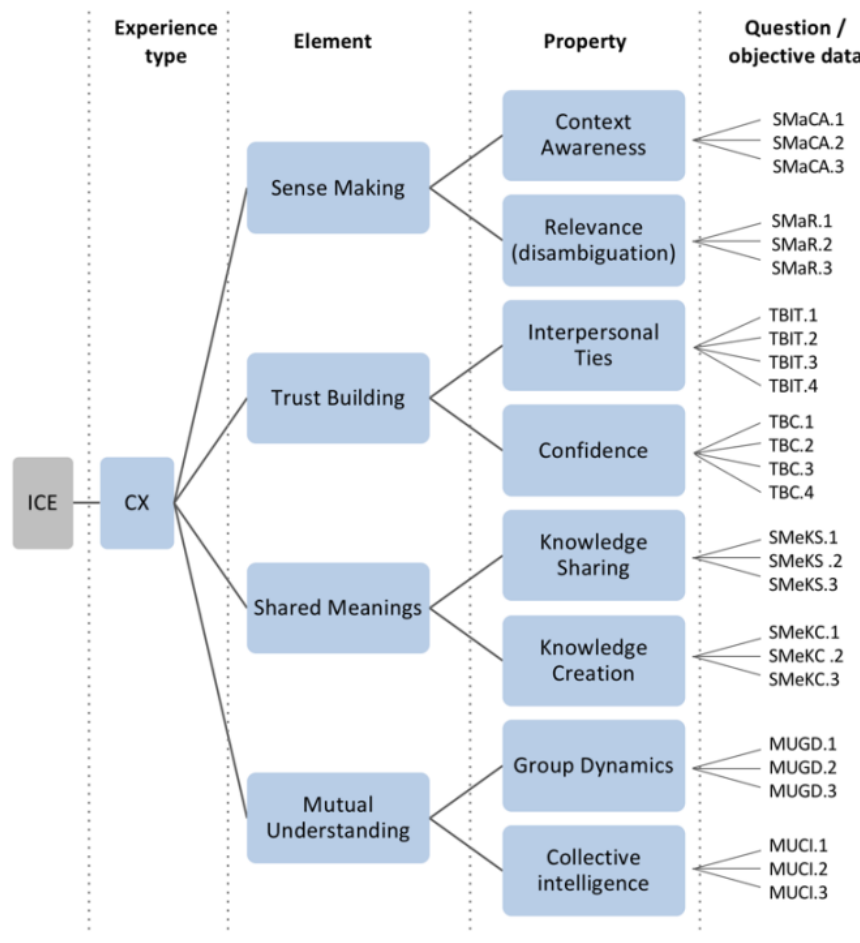

Figure 4: ICE Tree Structure for CX facet questions, adapted from $[1,2]$

Regarding the CX facet, each identified CX property gets three or four questions in order to evaluate the performance perceived by participants (Figure 4). Beside MU properties, some questions have the same antonyms because these questions address the self, the others and the group. The first question focuses on the personal appreciation while the second rates the interpretation of the behavior of teammates; then, the third question concerns the team (Appendix A.1).

For example, for SMaR, the three questions are: 1) during the exercise, how would you describe your comprehensiveness of your teammates? 2) During the exercise, how much your teammates were able to comprehend you? 3) During the exercise, how would you qualify the comprehensiveness between your teammates?

Regarding the rating scale, antonyms are: Incomprehensible Vs. Comprehensible. For the last property (Collective Intelligence), each question has its own antonyms that are semantic variant about loneliness or group action: Loneliness Vs. Togetherness;
Individually Vs. Collectively; Power relationship Vs. A consensus.

Finally, this facet has 26 questions and 11 antonyms. All these questions and their associated antonyms are original and come from our review of the literature and our findings during the first experiment. To complete the mixed methods approach, for each rating we add a qualitative question such as: 'explain briefly your motivation/reason behind your rating of ...'. This is intended to collect qualitative data that could explain why do we get this rating level.

\subsection{Evaluation of the IX dimension}

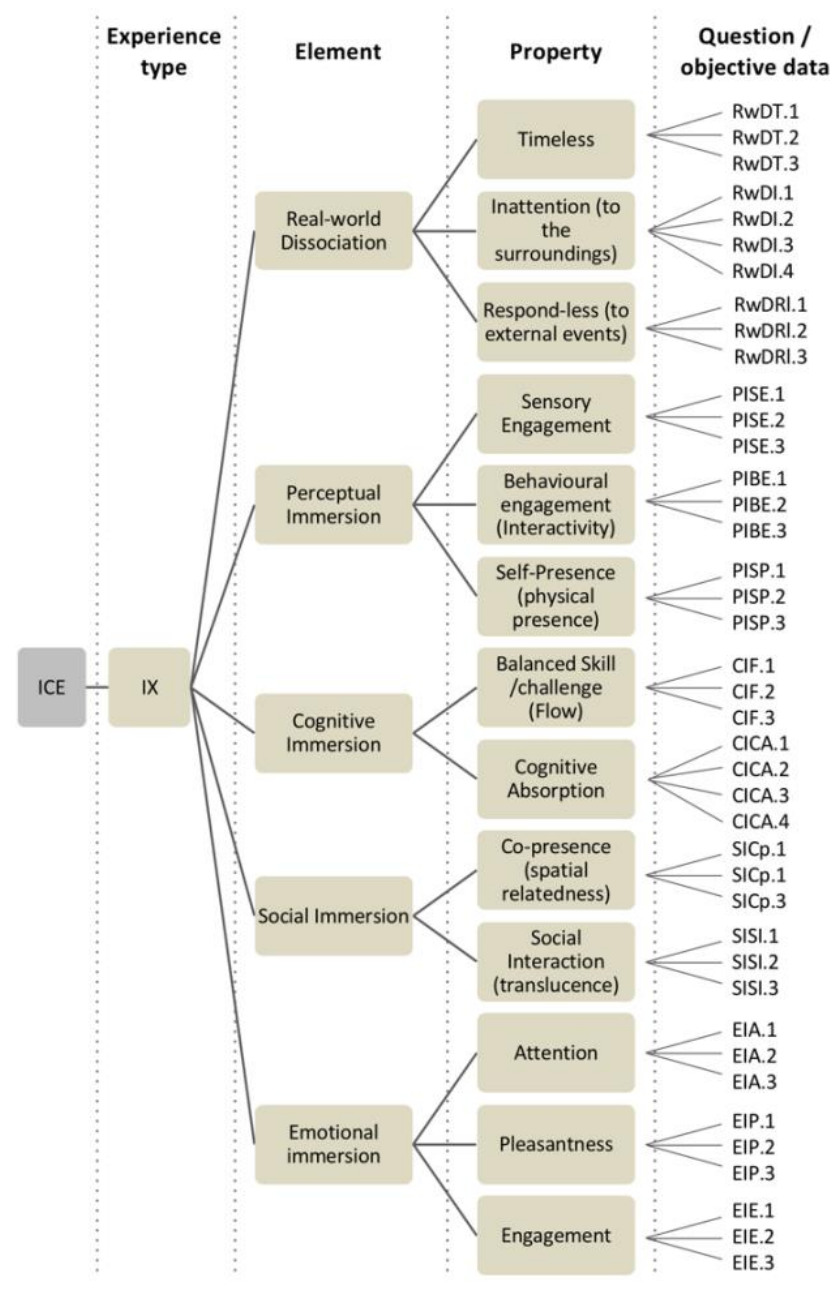

Figure 5: ICE Tree Structure for IX facet questions, adapted from $[1,2]$

As described above, Figure 5 shows that for each IX facet's property, we identified three or four questions to evaluate the performance. This facet has more properties than the CX facet. Indeed, 41 questions seem necessary to cover the range of 
intended properties. Furthermore, all questions have specific antonyms (Appendix A.2).

\subsection{Evaluation of the ICE acceptation}

Finally, this survey focuses on the acceptance and adoption of ICE as potential innovative technologies supporting co-creation and innovation. Table 3 presents the three questions dedicated to this causal effect.

Table 3: ICE acceptance \& adoption questions and antonyms

\begin{tabular}{|c|c|c|}
\hline Ref. & Questions & Antonyms \\
\hline \multicolumn{3}{|c|}{ Element: ICE Acceptance (ICEAcc) } \\
\hline ICEAcc. 1 & $\begin{array}{l}\text { - Please rate your level of } \\
\text { convincingness to the immersive space } \\
\text { for giving relevant result }\end{array}$ & $\begin{array}{l}\text { Unconvinced Vs. } \\
\text { Convinced }\end{array}$ \\
\hline ICEAcc. 2 & $\begin{array}{l}\text { - Please rate your level of willingness to } \\
\text { re-use an ICE }\end{array}$ & $\begin{array}{l}\text { Unwilling Vs. } \\
\text { Willing }\end{array}$ \\
\hline ICEAcc. 3 & $\begin{array}{l}\text { - Please rate how much you would } \\
\text { recommend ICE to teammates }\end{array}$ & $\begin{array}{l}\text { Reject Vs. } \\
\text { Recommend }\end{array}$ \\
\hline
\end{tabular}

\section{LIMITS}

\subsection{Acceptance and validity of the survey}

With 70 quantitative questions and the same amount of qualitative questions, this ICE evaluation framework could be quite long. Therefore, we suggest dividing this survey in three questionnaires: 1) the first one having CX questions, 2) the second one with the half of IX questions, 3) the third one with the remaining IX questions. We conclude these three questionnaires by the ICE acceptance $\&$ adoption questions.

Based on the statistical analysis of collected data and correlation factors, our goal is to reduce the number of properties and questions according to their relevance.

\subsection{Validity of the experiment}

To adequately compare our immersive technologies and their potential collaborative facet, it is necessary to generate the same kind of situation within the different platforms. For the moment, the LF2L immersive platforms are not able to support exactly the same content. For example, the LF2L ad hoc interface using Google Street View and designed for traditional display (2D vision) is not yet operational for HMD (HTC Vive platform). In this case, we assume the choice to consider LF2L as a global ICE, allowing the participants to use the four immersive platforms (a), (b), (c), (d) according to their needs (see Figure 2). In this case, we suggest comparing two situations: group of participants working together without immersive platform, then the same group using our immersive platforms.

\section{CONCLUSIONS}

We have designed the ICE model, constructs and mixed methods instrument based on the literature review and our own previous work and experiments. This is intended to identify and select the most relevant elements for the context of immersive co-creation. We assume that the exploratory aspect of our designed model and mixed methods instrument and our first experiment generated new knowledge and specific questions that we explored in order to strengthen a potential ICE universal evaluation framework.

While it is still on-going work, we hope to end-up with an interesting proposal of a universal ICE evaluation framework that would allow researchers to use it when needed in order to get a broader view in consolidating all collected data and findings.

As future work, we need to reconcile the immersive and collaborative experiences. The outcomes of the up-coming experiments will allow refining and eventually validating totally or partially this proposed ICE model, constructs and mixed methods instrument.

\section{ACKNOWLEDGMENTS}

This work was carried out in the context of collaboration between A\&M ParisTech P\&I Lab and Université de Lorraine, ERPI Laboratory through a research project dedicated to several experiments on immersive environments for co-creation. Authors wish to acknowledge their gratitude and appreciation to all colleagues and participants that contributed to this study.

\section{REFERENCES}

[1] Marc Pallot, Laurent Dupont, Olivier Christmann, Simon Richir, Boly Vincent, and Laure Morel. 2017. ICE Breaking: Disentangling Factors Affecting the Performance of Immersive Co-creation Environments,. In VRIC ' 17 Proceedings of the Virtual Reality International Conference. https://doi.org/10.1145/3110292.3110316

[2] Laurent Dupont, Marc Pallot, Laure Morel, Olivier Christmann, Vincent Boly, and Simon Richir. 2017. Exploring Mixed-methods Instruments for Performance Evaluation of Immersive Collaborative Environments. The International Journal of Virtual Reality 17, 2: 1-29.

[3] Venkat Ramaswamy and Francis J. Gouillart. 2010. The Power of Co-Creation: Build it with them to Boost Growth, Productivity, and Profits. Free Press., New York.

[4] Marc Pallot. 2009. The Living Lab Approach: A User Centred Open Innovation Ecosystem. Webergence Blog. Retrieved from https://web.archive.org/web/20120509081658/http://www.cweprojects.eu/pub/bscw.cgi/1760838?id=715404_176083

[5] Marc Pallot and K. S. Pawar. 2012. A Holistic Model of User Experience for Living Lab Experiential Design. In Proceedings of the 18th International Conference on Engineering, Technology and Innovation, ICE'2012 "Innovation by Collaboration and Entrepreneurial Partnerships."

[6] Ritu Agarwal and Elena Karahanna. 2000. Time Flies When You're Having Fun: Cognitive Absorption and Beliefs About Information Technology Usage. MIS Quarterly 24, 4: 665-694.

[7] Jeremy N. Bailenson, Jim Blascovich, Andrew C. Beall, and Jack M. Loomis. 2003. Interpersonal Distance in Immersive Virtual Environments. Personality and Social Psychology Bulletin 29, 7: 819-833. https://doi.org/10.1177/0146167203029007002

[8] Crystal L. Hoyt, Jim Blascovich, and Kimberly R. Swinth. 2003. Social Inhibition in Immersive Virtual Environments. In Presence: Teleoperators and Virtual Environments, 183-195. https://doi.org/10.1162/105474603321640932

[9] Emily Brown and Paul Cairns. 2004. A grounded investigation of game immersion. In Extended abstracts of the 2004 conference on Human factors and computing systems - CHI '04, 1297. https://doi.org/10.1145/985921.986048

[10] Gary Bente, Sabine Rüggenberg, and Nicole Krämer. 2004. Social Presence and Interpersonal Trust in Avatar-Based, Collaborative Net-Communications. 
In PRESENCE 2004: Proceedings of the 7th Annual International Workshop on Presence, 54-61.

[11] Michael Narayan, Leo Waugh, Xiaoyu Zhang, Pradyut Bafna, and Doug Bowman. 2005. Quantifying the benefits of immersion for collaboration in virtual environments. Proceedings of the ACM symposium on Virtual reality software and technology - VRST '05: 78. https://doi.org/10.1145/1101616.1101632

[12] Sandy Louchart, Ruth Aylett, Lynne Hall, Sarah Woods, and Ana Paiva. 2006. FearNot! Developing Social Immersion in the VICTEC and ECIRCUS Projects. In Ludovia 2006 Université du multimédia ludo-éducatif et pédagogique.

[13] Peter Antoniac, Marc Pallot, and Petri Pulli. 2006. Virtual and Augmented Reality Supporting Group Consciousness within Collaborative Working Environments. In 2006 IEEE International Technology Management Conference (ICE).

[14] Charlene Jennett, Anna L. Cox, Paul Cairns, Samira Dhoparee, Andrew Epps, Tim Tijs, and Alison Walton. 2008. Measuring and defining the experience of immersion in games. International Journal of Human Computer Studies 66, 9: 641-661. https://doi.org/10.1016/j.ijhcs.2008.04.004

[15] Charlene Jennett, Anna L. Cox, and Paul Cairns. 2009. Investigating computer game immersion and the component real world dissociation. In Proceedings of the 27th international conference extended abstracts on Human factors in computing systems - CHI EA '09, 3407. https://doi.org/10.1145/1520340.1520494

[16] Jeanne H. Brockmyer, Christine M. Fox, Kathleen A. Curtiss, Evan McBroom, Kimberly M. Burkhart, and Jacquelyn N. Pidruzny. 2009. The development of the Game Engagement Questionnaire: A measure of engagement in video gameplaying. Journal of Experimental Social Psychology 45, 4: 624-634. https://doi.org/10.1016/j.jesp.2009.02.016

[17] Keith Stuart. 2010. What do we mean when we call a game immersive? The Guardian. Retrieved March 10, 2017 from http://www.theguardian.com/technology/gamesblog/2010/aug/10/gamesscience-of-immersion

[18] Timothy Sanders and Paul Cairns. 2010. Time perception, immersion and music in videogames. In Proceedings of the 24th BCS Interaction Specialist Group Conference, 160-167.

[19] Gordon Calleja. 2011. In-Game: From Immersion to Incorporation. The MIT Press; 1 edition (May 13, 2011).

[20] Paul Gestwicki and Ronald Morris. 2012. Social Studies Education Game Development as an Undergraduate Immersive Learning Experience. In Handbook of Research on Serious Games as Educational, Business and Research Tools. IGI Global, 838-858. https://doi.org/10.4018/978-1-46660149-9.ch043

[21] Amy Shirong Lu, Tom Baranowski, Debbe Thompson, and Richard Buday. 2012. Story Immersion of Videogames for Youth Health Promotion: A Review of Literature. Games for Health Journal 1, 3: 199-204. https://doi.org/10.1089/g4h.2011.0012

[22] Pollyana Notargiacomo Mustaro and Raphael Leal Mendonça. 2012. Immersion, Narrative, and Replayability as the Motivational and Attractiveness Factors in Serious Games. In Handbook of Research on Serious Games as Educational, Business and Research Tools. IGI Global, 991-1008. https://doi.org/10.4018/978-1-4666-0149-9.ch051

[23] Marc Pallot. 2012. Collaborative Distance: Investigating Distance Factor Affecting Collaboration Performance. LAP LAMBERT Academic Publishing.

[24] Simone Schnall, Craig Hedge, and Ruth Weaver. 2012. The Immersive Virtual Environment of the digital fulldome: Considerations of relevant psychological processes. International Journal of Human Computer Studies 70, 8: 561-575. https://doi.org/10.1016/j.ijhcs.2012.04.001

[25] Carlos Miguel Lorenzo, Miguel Ấngel Sicilia, and Salvador Sánchez. 2012. Studying the effectiveness of multi-user immersive environments for collaborative evaluation tasks. Computers and Education 59, 4: 1361-1376. https://doi.org/10.1016/j.compedu.2012.06.002

[26] Laurent Dupont, Vida Gholipour, Laure Morel, Jean-Claude Bignon, and Claudine Guidat. 2012. From Urban Concept to Urban Engineering: The Contribution of Distributed Collaborative Design to the Management of Urban Projects. Journal of Urban Design 17, 2: 255-277. https://doi.org/10.1080/13574809.2012.666208

[27] Livia Ştefan. 2012. Immersive Collaborative Environments for Teaching and Learning Traditional Design. Procedia - Social and Behavioral Sciences 51: 1056-1060. https://doi.org/10.1016/j.sbspro.2012.08.287

[28] Anna Cox, Paul Cairns, Pari Shah, and Michael Carroll. 2012. Not Doing But Thinking: The Role of Challenge in the Gaming Experience. In CHI'2012 ACM annual conference on Human Factors in Computing Systems, 79-88. https://doi.org/10.1145/2207676.2207689

[29] Matt Thompson, Ai Nordin, and P Cairns. 2012. Effect of touch-screen size on game immersion. In Proceedings of the 26th Annual BCS HCI 2012 People \& Computers, 280-285. Retrieved from http://dl.acm.org/citation.cfm?id=2377952
[30] Ismael H.F. Santos, Luciano P. Soares, Felipe Carvalho, and Alberto Raposo. 2012. A collaborative virtual reality oil \& gas workflow. The International Journal of Virtual Reality 11, 1: 1-13.

[31] Marc Pallot, Remy Eynard, Benjamin Poussard, Olivier Christmann, and Simon Richir. 2013. Augmented sport: exploring collective user experience. In Proceedings of the Virtual Reality International Conference on Laval Virtual VRIC '13, 1. https://doi.org/10.1145/2466816.2466821

[32] A. Imran Nordin, Jaron Ali, Aishat Animashaun, Josh Asch, Josh Adams, and Paul Cairns. 2013. Attention, time perception and immersion in games. In CHI'13 Extended Abstracts on Human Factors in Computing Systems on - CHI EA '13, 1089-1094. https://doi.org/10.1145/2468356.2468551

[33] Marija Nakevska, Anika van der Sanden, Mathias Funk, Jun Hu, and Matthias Rauterberg. 2014. Interactive Storytelling in a Mixed Reality Environment: The Effects of Interactivity on User Experiences. Entertainment Computing--ICEC 2014: 52-59. https://doi.org/10.1016/j.entcom.2017.01.001

[34] Armando Cruz, Hugo Paredes, Benjamim Fonseca, and Leonel Morgado. 2014 Can Presence Improve Collaboration in 3D Virtual Worlds? Procedia Technology 13: 47-55. https://doi.org/10.1016/j.protcy.2014.02.008

[35] A. Imran Nordin, Alena Denisova, and Paul Cairns. 2014. Too Many Questionnaires: Measuring Player Experience Whilst Playing Digital Games. In Seventh York Doctoral Symposium on Computer Science \& Electronics, 69-75. https://doi.org/10.1007/s11031-006-9051-8

[36] Laura Freina and Michela Ott. 2015. A literature review on immersive virtual reality in education: State of the art and perspectives. In Proceedings of eLearning and Software for Education (eLSE)(Bucharest, Romania, April 2324, 2015), 8. https://doi.org/10.12753/2066-026X-15-020

[37] Remy Eynard, Marc Pallot, Olivier Christmann, and Simon Richir. 2015. Impact of Verbal Communication on User Experience in 3D Immersive Virtual Environments. In IProceedings of the International Conference on Engineering, Technology and Innovation (ICE), ICE'2015.

[38] Daniel E. Orenstein, Hagit Zimroni, and Efrat Eizenberg. 2015. The immersive visualization theater: A new tool for ecosystem assessment and landscape planning. Computers, Environment and Urban Systems 54: 347-355. https://doi.org/10.1016/j.compenvurbsys.2015.10.004

[39] Christian Roth. 2015. Experiencing Interactive Storytelling. Vrije University, Amsterdam.

[40] Laurent Dupont, Marc Pallot, and Laure Morel. 2016. Exploring the Appropriateness of Different Immersive Environments in the Context of an Innovation Process for Smart Cities. Technology Management Conference.

[41] Chenyan Zhang, Aud Sissel Hoel, and Andrew Perkis. 2016. Quality of Immersive Experience in Storytelling: A Framework. In Eighth International Workshop on Quality of Multimedia Experience QoMEX 2016, 12.

[42] Fengfeng Ke and Peter Carafano. 2016. Collaborative science learning in an immersive flight simulation. Computers and Education 103: 114-123. https://doi.org/10.1016/j.compedu.2016.10.003

[43] Marc Pallot and Simon Richir. 2016. Laval Virtual Vision 2025 : Blurring the lines between digital and physical worlds. In Proc. 11th Intl Conf. Disability, Virtual Reality \& Associated Technologies, 1-9.

[44] Berenice Serrano, Rosa M. Baños, and Cristina Botella. 2016. Virtual reality and stimulation of touch and smell for inducing relaxation: A randomized controlled trial. Computers in Human Behavior 55: 1-8. https://doi.org/10.1016/j.chb.2015.08.007

[45] Lauriane Pouliquen-Lardy. 2016. Collaboration à distance: étude de la compréhension mutuelle dans les environnements virtuels collaboratifs immersifs - Le cas de lacommunication spatiale. RENNES 2.

[46] Sebastian Ulewicz, Dorothea Pantförder, and Birgit Vogel-Heuser. 2016. Interdisciplinary Communication and Comprehension in Factory Automation Engineering - A Concept for an Immersive Virtual Environment. IFACPapersOnLine 49, 19: 227-232. https://doi.org/10.1016/j.ifacol.2016.10.529

[47] Daniel Gábana Arellano, Laurissa Tokarchuk, and Hatice Gunes. 2016. Measuring affective, physiological and behavioural differences in solo, competitive and collaborative games. In 8th International Conference on Intelligent Technologies for Interactive Entertainment - Intertain (June, 28-30), $1-10$.

[48] Christian Roth and Hartmut Koenitz. 2016. Evaluating the User Experience of Interactive Digital Narrative. In Proceedings of the 1st International Workshop on Multimedia Alternate Realities - AltMM '16, 31-36. https://doi.org/10.1145/2983298.2983302

[49] Khanh-Duy Le, Morten Fjeld, Ali Alavi, and Andreas Kunz. 2017. Immersive environment for distributed creative collaboration. Proceedings of the 23rd ACM Symposium on Virtual Reality Software and Technology - VRST '17: 1-4. https://doi.org/10.1145/3139131.3139163

[50] Qing-Ke Fu and Gwo-Jen Hwang. 2018. Trends in mobile technology-supported collaborative learning: A systematic review of journal publications from 2007 to 2016. Computers \& Education 119, December 2017: 129-143. 
https://doi.org/10.1016/j.compedu.2018.01.004

[51] Jing Du, Zhengbo Zou, Yangming Shi, and Dong Zhao. 2018. Zero latency: Real-time synchronization of BIM data in virtual reality for collaborative decision-making. Automation in Construction 85, October 2017: 51-64. https://doi.org/10.1016/j.autcon.2017.10.009

[52] Xiao Li, Wen Yi, Hung Lin Chi, Xiangyu Wang, and Albert P.C. Chan. 2018. A critical review of virtual and augmented reality (VR/AR) applications in construction safety. Automation in Construction 86, October 2017: 150-162. https://doi.org/10.1016/j.autcon.2017.11.003

[53] Ken Dovey. 2009. The role of trust in innovation. The Learning Organization $16, \quad 4: \quad 311-325$ https://doi.org/http://dx.doi.org/10.1108/09696470910960400

[54] Rahmat Shazi, Nicole Gillespie, and John Steen. 2015. Trust as a predictor of innovation network ties in project teams. International Journal of Project Management 33, 1: 81-91. https://doi.org/10.1016/j.ijproman.2014.06.001

[55] Piotr Krawczyk, M. Topolewskil, and Marc Pallot. 2017. Towards a Reliable and Valid Mixed Methods Instrument in User eXperience Studies. In 2017 International Conference on Engineering, Technology and Innovation (ICE/ITMC), 1497-1506

\section{A ICE SURVEY}

\section{A.1 CX questions and antonyms}

\begin{tabular}{lll}
\hline Ref. & Questions & Antonyms \\
\hline Element: Sense Making & \\
\hline Property: Context Awareness & \\
\hline SMaCA.1 & - In the study context, what was your & \\
awareness of the challenges to be & & \\
tackled? & - Would you say that your teammates & Unaware \\
wMaCA.3 & $\begin{array}{l}\text { context of the study? } \\
\text { - Would you say that the team was } \\
\text { aware of the challenges in the context } \\
\text { of the study? }\end{array}$ & Aware
\end{tabular}

Property: Relevance (Disambiguation)

SMaR.1 - During the exercise, how would you

describe your comprehensiveness of your teammates?

SMaR.2 - During the exercise, how much your teammates were able to comprehend you?

Incomprehensible Vs.

Comprehensible

SMaR.3 - During the exercise, how would you qualify the overall comprehensiveness between your teammates?

Element: Trust Building

\begin{tabular}{lll}
\hline Property: Interpersonal Ties & \\
\hline TBIT.1 & - Would you say that you were with & \\
TBIT.2 & your teammates? & \\
& - Would you say that your teammates & \\
TBIT.3 & - Were with you? & Pointless \\
& were between them? & Vs. \\
TBIT.4 & - Would you say that relationships & \\
& inside the team were? & \\
& & \\
Property: Confidence & Unconfident \\
\hline TBC.1 & - With your teammates, you felt? & Vs. \\
TBC. 2 & - Would you say your teammates were & Confident
\end{tabular}

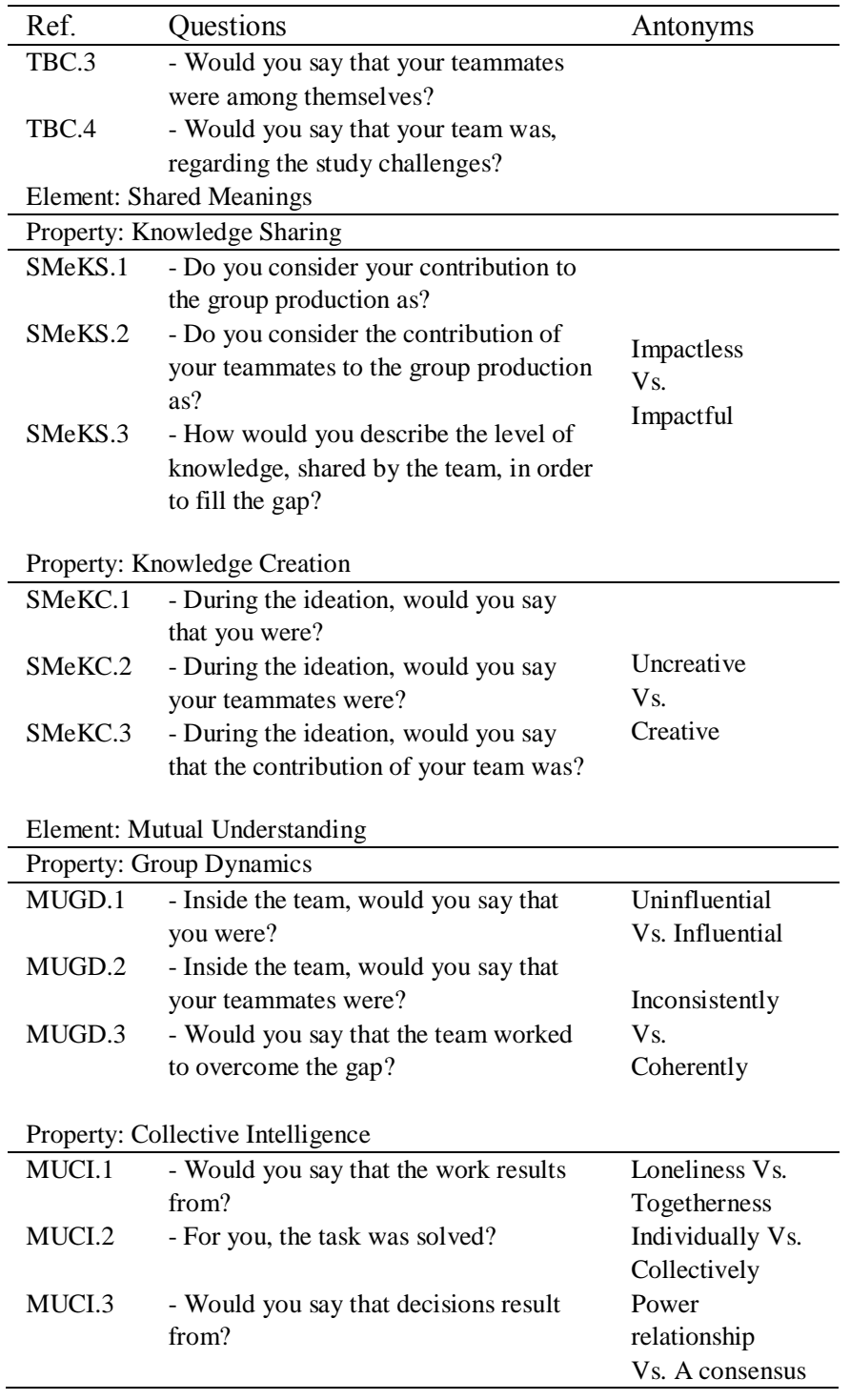

\section{A.2 IX questions and antonyms}

\begin{tabular}{lll}
\hline Ref. & Questions & Antonyms \\
\hline \multicolumn{2}{l}{ Element: Real-world Dissociation } & \\
\hline Property: Timeless & Unconcerned Vs. \\
\hline RwDT.1 & - Would you say that the team & Friendly \\
& atmosphere was? & Inconsistent Vs. \\
RwDT.2 & - Would you say that exchanges & Permanent \\
& between teammates were? & Boring Vs. \\
RwDT.3 & - Would you say that to overcome the & Captivating \\
& gap was? & \\
Property: Inattention (to the surroundings) & Inharmonious \\
\hline RwDI.1 & - Would you say that you and your & Vs. Harmonious \\
& teammates in the immersive space & \\
RwDI.2 & were? & Partially Vs.
\end{tabular}




\begin{tabular}{ll}
\hline Ref. & Questions \\
\hline \multirow{3}{*}{ RwDI.3 } & immersive space? \\
& - Would you say that external \\
& phenomena (e.g. noise, smell, etc.) \\
& outside from the immersive space \\
RwDI.4 & were? \\
& - Would you say that you were to \\
& external environment from immersive \\
& space?
\end{tabular}

Antonyms

Disturbing

Vs. Tenuous

Inattentive

Vs. Attentive

Property: Respond-less (to external events)

RwDRl.1 - Your reaction (voice or gestura
response) to request from the outside environment (noise, other people, furniture, ...) was...

RwDR1.2 - How would you describe the team's work in relation to the influence of an event outside the immersive space?

RwDRl.3 - In relation to its external environment, you would say that the immersive space was?

Element: Perceptual Immersion

\begin{tabular}{lll}
\hline Property: & Sensory engagement (visual, audio, tactile) & \\
\hline PISE.1 & - Would you say that what happened in & Imperceptible \\
& the immersive space was? & Vs. Perceptible \\
PISE.2 & - Would you say that what happened in & Virtual Vs. \\
& the immersive space was? & Real \\
PISE.3 & - How would you characterize your & Strenuous \\
& $\begin{array}{l}\text { sensory engagement in the immersive } \\
\text { space? }\end{array}$ & Vs. \\
& Easy
\end{tabular}

Property: Behavioral engagement (interactivity / reflex)

$\begin{array}{ll}\text { PIBE.1 } & \text { - Would you say that to act in the } \\ & \text { immersive space you felt? }\end{array}$
immersive space you felt?

PIBE.2 - How would you qualify the interactiveness within your environment in the immersive space?

PIBE.3 - Would you say the immersive space was?

Unchanged Vs. Transformed

Isolated Vs. Opened Unreactive Vs. Reactive

\section{Hesitant Vs.} Spontaneous Dissociated Vs. Associated

Adverse Vs. Enabling

Property: Self-Presence (physical presence)

PISP.1 - Would you say that inside the
immersive space you were?

PISP.2 - Would you say that your interactions with the immersive space seemed?

PISP.3 - Would you say that the immersive space allowed you to explore the situation?

Element: Cognitive Immersion Property: Balanced Skill/challenge (Flow)

\begin{tabular}{lll}
\hline CIF.1 & - What level of expertise did you have & Novice Vs. \\
& at the beginning of the mission to use & Expert
\end{tabular}
the immersive space?

CIF.2 - What level of expertise did you have at the end of the mission to use the immersive space?

CIF.3 - How would you qualify the level of control of the situation in the immersive space?

\begin{tabular}{lll}
\hline Ref. & Questions & Antonyms \\
\hline CICA.1 & $\begin{array}{l}\text { - What level of interest did you feel at } \\
\text { the beginning of the mission in the }\end{array}$ & $\begin{array}{l}\text { Uninterested } \\
\text { Vs. Interested }\end{array}$ \\
immersive space? & $\begin{array}{l}\text { - What level of interest did you feel at } \\
\text { the end of the mission in the immersive }\end{array}$ & Uninterested \\
CICA.2 & Vs. Interested
\end{tabular}
space?

CICA.3 - How do you qualify your degree of attraction for the immersive space?

CICA.4 - How would you describe the usefulness of the immersive space to overcome the gap?

Unattractive Vs. Attractive Useless Vs. Useful

Element: Social Immersion Property: Co-presence (spatial relatedness)

\begin{tabular}{lll}
\hline SICp.1 & $\begin{array}{l}\text { - How would you describe your } \\
\text { listening to your team in the immersive } \\
\text { space? }\end{array}$ & $\begin{array}{l}\text { Inattentive } \\
\text { Vs. Attentive }\end{array}$ \\
SICp.2 & $\begin{array}{l}\text { - How would you describe your team's } \\
\text { commitment in the immersive space? }\end{array}$ & $\begin{array}{l}\text { Uncommitted } \\
\text { Vs. Committed }\end{array}$ \\
SICp.3 & $\begin{array}{l}\text { - How would you describe the presence } \\
\text { of your teammates with you in the }\end{array}$ & $\begin{array}{l}\text { Absent Vs. } \\
\text { Present }\end{array}$
\end{tabular}
immersive space?

Property: Social Interaction (translucence)

\begin{tabular}{lll}
\hline SISI.1 & $\begin{array}{l}\text { - How would you describe your activity } \\
\text { with your team in the immersive space? }\end{array}$ & $\begin{array}{l}\text { Passive Vs. } \\
\text { Active }\end{array}$ \\
SISI.2 & $\begin{array}{l}\text { - How would you describe the } \\
\text { coordination of your interaction with } \\
\text { your team in the immersive space? }\end{array}$ & Concerted \\
SISI.3 & $\begin{array}{l}\text { - How would you describe your } \\
\text { understanding of what to do in the } \\
\text { immersive space? }\end{array}$ & $\begin{array}{l}\text { Inductive Vs. } \\
\text { Deductive }\end{array}$ \\
\end{tabular}

Element: Emotional immersion

\begin{tabular}{|c|c|c|}
\hline \multicolumn{3}{|c|}{ Property: Attention } \\
\hline EIA.1 & $\begin{array}{l}\text { - Would you say that the task in the } \\
\text { immersive space made you feel? }\end{array}$ & $\begin{array}{l}\text { Unconcerned } \\
\text { Vs. Concerned }\end{array}$ \\
\hline EIA.2 & $\begin{array}{l}\text { - Would you say that the immersive } \\
\text { space made you feel with your team? }\end{array}$ & $\begin{array}{l}\text { Not in symbiosis } \\
\text { Vs. In symbiosis }\end{array}$ \\
\hline EIA.3 & $\begin{array}{l}\text { - Would you say that in the immersive } \\
\text { space you were? }\end{array}$ & $\begin{array}{l}\text { Inattentive Vs. } \\
\text { Attentive }\end{array}$ \\
\hline \multicolumn{3}{|c|}{ Property: Pleasantness } \\
\hline EIP.1 & $\begin{array}{l}\text { - Would you say that the immersive } \\
\text { space made you feel? }\end{array}$ & $\begin{array}{l}\text { Embarrassed Vs. } \\
\text { Comfortable }\end{array}$ \\
\hline EIP.2 & $\begin{array}{l}\text { - Would you say that the immersive } \\
\text { space made you feel with your team? }\end{array}$ & $\begin{array}{l}\text { Unconfident } \\
\text { Vs. Confident } \\
\text { Unpleasant }\end{array}$ \\
\hline EIP.3 & $\begin{array}{l}\text { - Would you say that the work in the } \\
\text { immersive space was emotionally? }\end{array}$ & Vs. Pleasant \\
\hline \multicolumn{3}{|c|}{ Property: Engagement } \\
\hline EIE.1 & $\begin{array}{l}\text { - Would you say that the task in the } \\
\text { immersive space was emotionally? }\end{array}$ & $\begin{array}{l}\text { Repulsive Vs. } \\
\text { Attractive }\end{array}$ \\
\hline EIE.2 & $\begin{array}{l}\text { - Would you say that in the immersive } \\
\text { space you and your teammates felt } \\
\text { emotionally? }\end{array}$ & $\begin{array}{l}\text { Disconnected } \\
\text { Vs. Connected }\end{array}$ \\
\hline EIE. 3 & $\begin{array}{l}\text { - How would you characterize the } \\
\text { emotional engagement produced by the } \\
\text { task in the immersive space? }\end{array}$ & $\begin{array}{l}\text { Uncommitted } \\
\text { Vs. } \\
\text { Committed }\end{array}$ \\
\hline
\end{tabular}
task in the immersive space?

Committed

Property: Cognitive Absorption

Novice Vs. Expert

Not in control

Vs.

In control

Absent Vs.

Present

Restrictively Vs. Exhaustively 